\title{
Pseudomonas chlororaphis
}

National Cancer Institute

\section{Source}

National Cancer Institute. Pseudomonas chlororaphis. NCI Thesaurus. Code C86699.

A species of aerobic, Gram negative, rod shaped bacteria in the phylum Proteobacteria.

This species is motile, non spore forming, can use 5 ketogluconate as a source of carbon

and produces chlororaphin. P. chlororaphis is not a pathogen and some subspecies are used as an agricultural fungicide. 